Hevko I. V. Influence of the emotionally positive attitude on forming the communicative competences of technology teachers. Pedagogy and Psychology of Sport. 2017;3(2):48-56. eISSN 2450-6605. DOI http://dx.doi.org/10.5281/zenodo.831674

http://apcz.umk.pl/czasopisma/index.php/PPS/article/view/PPS.2017.010

Original text

Hevko I. V. Influence of the emotionally positive attitude on forming the communicative competences of technology teachers. Journal of Education, Health and Sport. 2017;7(2):593-600. eISSN 2391-8306. DOI http://dx.doi.org/10.5281/zenodo.584137 http://ojs.ukw.edu.pl/index.php/johs/article/view/4492

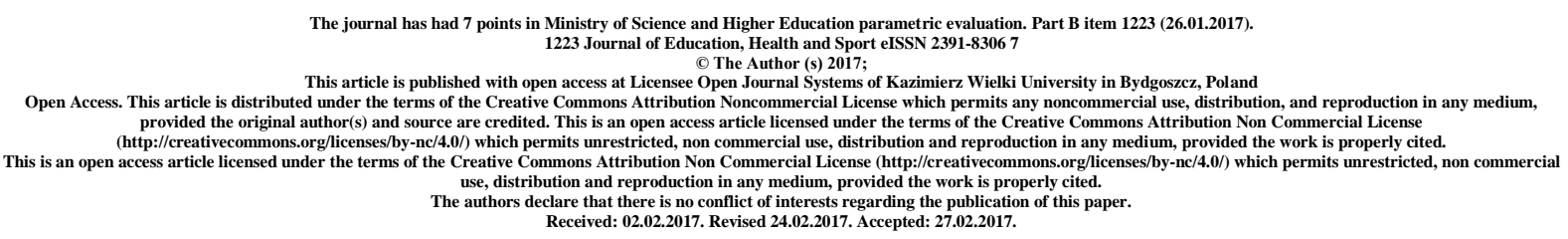

UDK 378.147

\title{
INFLUENCE OF THE EMOTIONALLY POSITIVE ATTITUDE ON FORMING THE COMMUNICATIVE COMPETENCES OF TECHNOLOGY TEACHERS
}

\author{
Igor Vasilievich Hevko
}

\section{Ternopil National Pedagogical University Volodymyr Hnatyuk}

\section{Abstract}

The article reveals the influence of an emotionally positive attitude on the formation of communicative competences of technology teachers. In the article under communicative competence, the author considers the quality of a person characterized by certain properties, in particular by properties that necessary for perceptual activity, personal-communicative and communicative-operational activities. It is proved that the creation of an emotionally positive mood in the learning environment acts as one of the factors of pedagogical stimulation in our study and the formation of the communicative competence of the future specialist in the technological profile.

Key words: emotional-positive attitude, communicative competence, perceptual activity, personality-communicative activity, communicative-operational activity 


\title{
ВЛИЯНИЕ ЭМОЦИОНАЛЬНО-ПОЛОЖИТЕЛЬНОГО НАСТРОЯ НА ФОРМИРОВАНИЕ КОММУНИКАТИВНЫХ КОМПЕТЕНЦИЙ УЧИТЕЛЕЙ ТЕХНОЛОГИЙ
}

\author{
И. В. Гевко \\ Тернопольский национальный педагогический университет \\ имени Владимира Гнатюка
}

В статье раскрыто влияние эмоционально-положительного настроя на формирование коммуникативных компетенций учителей технологий. В статье под коммуникативной компетентностью автор рассматривает качество личности, характеризуемое определенными свойствами, в частности свойствами необходимыми для проведения перцептивной деятельности, личностно-коммуникативной и коммуникативно-операциональной деятельности. Доказано, что создание эмоционально-положительного настроения в учебной среде выступает как один из факторов педагогического стимулирования, в нашем исследовании, формирования коммуникативной компетентности будущего специалиста технологического профиля.

Ключевые слова: эмоционально-положительный настрой, коммуникативные компетентности, перцептивная деятельность, личностнокоммуникативная деятельность, коммуникативно-операциональная деятельность.

\section{ВПЛИВ ЕМОЦЙНО-ПОЗИТИВНОГО НАСТРОЮ НА ФОРМУВАННЯ КОМУНІКАТИВНИХ КОМПЕТЕНТНОСТЕЙ ВЧИТЕЛІВ ТЕХНОЛОГІЙ}

\author{
I. В. Гевко
}

Тернопільський національний педагогічний університет ім.. Володиира Гнатюка 
У статті розкрито вплив емоційно-позитивного настрою на формування комунікативних компетентностей вчителів технологій. В статті під комунікативною компетентністю автором розглядає якість особистості, яка характеризується певними властивостями, зокрема властивостями необхідними для проведення перцептивної діяльності, особисто-комунікативної та комунікативно-операціональної діяльності. Доведено, що створення емоційно-позитивного настрою в навчальному середовищі виступає як один 3 факторів педагогічного стимулювання в нашому дослідженні формування комунікативної компетентності майбутнього фахівця 3 технологічного фaxy.

\section{Ключові слова: емоційно-позитивний настрій, комунікативні компетентності, перцептивна діяльності, особисто-комунікативна діяльність, комунікативно-операціональна діяльність.}

В умовах модернізації навчального процесу у вищій школі, що передбачена Національною доктриною розвитку освіти і державними заходами щодо входження української освіти і науки в європейський освітній простір, особливого значення набуває проблема підготовки висококваліфікованого фахівця - вчителя, вихователя, керівника навчального закладу.

Для того, щоб здійснювати педагогічну діяльність на досить високому рівні, учитель повинен бути професіоналом. Його компетентність визначається професійними знаннями і вміннями, 3 одного боку, і професійною позицією, психологічними якостями - 3 іншого.

Аналіз останіх досліджень і публікацій. Професіоналізм педагога доцільно розглядати як домінуючий фактор забезпечення позитивної динаміки якості освіти, особистісного і професійного зростання учнів і самого педагога, їх продуктивної самореалізації. Отже підвищення кваліфікації і самоосвіта стають одними з умов оновлення, насичення i удосконалення педагогом особистісних i професійних цінностей, мотивів, знань, компетенцій, якостей, властивостей і ставлень.

Розв’язання цих складних проблем робить актуальним завдання усвідомлення науково-практичних і методологічних підходів до професійної педагогічної освіти.

За останні роки ми бачимо збільшення інтересу науковців і практиків до проблеми професіоналізму і професійної компетентності фахівців - державних службовців; політологів; соціальних працівників; працівників системи освіти [ 2, 4, 7 ]. 
Потенціал фахівця може бути виявлено у його основних професійнообумовлених структурах особистості, діяльності, спілкування. Сформованість яких буде характеризувати той чи інший рівень його професіоналізму. Аналіз результатів досліджень В. В. Борисова, В. М. Вакуленко, В. М. Гриньовой, Н. В. Гузій, Б. С. Гершунського, М. Б. Євтуха, Л. Л. Макаренко, В. О. Сластьоніна, А. Ю. Цини дають нам підстави стверджувати, що провідним компонентом професійного потенціалу педагога є компетентність. В нашому випадку це професійна компетентність вчителя технологій.

Формулювання цілей статті (постановка завдання). Здійснити аналіз науково-педагогічної літератури 3 проблеми професійної компетентності сучасного вчителя технологій та на її основі визначити вплив емоційно-позитивного настрою на формування комунікативної компетентності вчителів технологій.

Виклад основного матеріалу дослідження 3 повним обгрунтуванням отриманих наукових результатів.

Однією з важливих вимог до професійної підготовки майбутнього фахівця $є$ формування комунікативної компетентності. Під комунікативною компетентністю ми розуміємо якість особистості, яка характеризується такими властивостями:

1) властивості, необхідні для проведення перцептивної діяльності;

2) властивості, необхідні для проведення особисто-комунікативної діяльності;

3) властивості, необхідні для проведення комунікативно-операціональної діяльності.

До першої групи властивостей відносимо - здатність до сприйняття, розуміння, самовираження. До другої - вміння відновити попередню діяльність, пов'язану 3 професійним спілкуванням, передавати інформацію, організувати спільну діяльність, керувати процесом професійного спілкування, аналізувати вчинки партнерів по спілкуванню, проектувати майбутне професійне спілкування. До третьої групи відносимо властивості, які сприяють управлінню собою, і управлінню іншими в процесі спілкування - володіння всією технікою спілкування, вербальною і невербальною. Слід зазначити, що, на всіх трьох рівнях емоційний настрой відіграє основну роль - здатність керувати своїми емоціями, самосвідомістю, контроль імпульсивності, впевненість, самомотивація, оптимізм, вміння ефективно вибудовувати взаємини з іншими людьми. Сьогодні в психолого-педагогічній літературі подібні здібності особистості розглядають в якості емоційної компетентності. Емоційна компетентність включає в себе вміння точно розпізнавати, оцінювати і виражати 
емоції; вміння досягати і породжувати почуття, коли це допомогає процесу мислення; вміння розуміти емоції і емоційний знання; а також вміння керувати емоціями для досягнення емоційного та інтелектуального зростання.

За підсумками бесід, опитувань, тестів студентів, викладачів інженернопедагогічного факультету Тернопільського педагогічного університету імені Володимира Гнатюка, нами виявлено основні риси характеру, здібності особистості, що сприяють формуванню комунікативної компетентності це - оптимізм, відкритість, уважність, здатність до співпереживання, сміливість, гнучкість, ініціативність, і відповідно ускладнюють цей процес - песимізм, звинувачення, засудження, не вміння прощати, скутість, несміливість, розсіяність, відчуженість, позиція захисту.

Ми вважаємо, що створення емоційно-позитивного настрою в навчальному середовищі виступає як один з факторів педагогічного стимулювання в нашому дослідженні формування комунікативної компетентності майбутнього фахівця 3 технологічного фаху.

Залежно від настрою, в якому людина звертається до тієї чи іншої проблематики, він може прийти до різних висновків і оцінок. Емоції розглядаються як найважливіший фактор регуляції процесів пізнання: вони утворюють певний простір, всередині якого відбуваються розумові процеси. Гарний настрій і позитивні емоції сприяють гнучкості мислення і впровадження оригінальних ідей. Р. У. Ліпер, зазначає, що емоції є першочерговими мотивуючими факторами, оскільки емоційні процеси дозволяють спонукати активність, підтримувати іiі і керувати нею [6]. «Емоція - це щось, що переживається як почуття, яке мотивує, організовує і направляє сприйняття, мислення і дії» [4, с. 27].

О. К. Тихомиров показує, що інтелектуальний процес неможливий без емоційної активації [5]. Представники цієї школи вказали на існування двох феноменів, пов'язаних $з$ взаємодією афективних і когнітивних процесів, таких як «емоційний виявлення рішення» $\mathrm{i}$ «емоційне виявлення проблеми». [2, с. 273].

У нашому дослідженні педагогічне стимулювання комунікативної компетентності майбутнього фахівця, вміння управляти своїми емоціями та емоціями оточуючих - важливий фактор ефективності комунікативної діяльності. При переживанні позитивних емоцій під час навчальних занять працездатність студентів підвищується на 30-40\%, а емоційність лежить в основі близько 30\% факторів, які формують ставлення студентів до лекцій [3]. 
Позитивний настрій є такою ж необхідною частиною ділової людини, як і його костюм. Часом для прийняття рішення необхідно розрядити обстановку, відволіктися від серйозних проблем, поліпшити настрій собі і оточуючим.

Тільки доброзичливими відносинами між викладачем i учнями можна сформувати потребу в навчанні. Одним з важливих чинників у створенні позитивного настрою в процесі навчання є роль особистості викладача.

До загального переліку якостей викладача, які найбільше цінують студенти, згідно з опитуванням, відносять: широкий кругозір, захопленість викладача предметом i знання його, інтерес до особистості студента, повагу, терпимість, розуміння, доброзичливість, справедливість. А до якостей, які відштовхують, відносять - низький рівень культури, нахабство, нетерпимість, фальш, приниження гідності студента, жорстокість, злість, агресивність. Для підняття авторитету викладач повинен бути «магнітом» для учнів. «Бути то грізним, що лякає, який змушує побоюватися ... і не тиснути на них незліченними розмовами. Бути шанованим і шанованим ... бути чіткіше, вагоміше ... оволодіти мистецтвом звернути на себе увагу словом »[8, с. 100].

Викладач - професіонал, ось що виходить на перший план сьогодні. Елері Семпсон розділяє професіоналізм на п’ять складових: компетентність, впевненість, довіру, сталість і контроль. Під контролем розуміється контроль над своїми емоціями, вміння контролювати інших, контролювати виконання проектів. Впевненість виражається навіть у зовнішності: людина стоїть прямо, дихає легко, не боїться дивитися в очі, відчуває себе добре підготовленим, поінформованим. Компетентність автор визначає як «знати в чому саме ти перевищив своїх конкурентів» [7, с.62]. Незважаючи на розмитість даних якостей, ми знаходимо в них основні принципи ведення будь-якої діяльності.

У нашому дослідженні, при комунікативній діяльності викладач, будучи компетентним у знанні свого предмету, повинен виражати впевненість, яка обов'язково передасться всім учасникам комунікативного процесу. Впевненість розглядається нами як одна з якостей, що впливають на ефективність застосування таких механізмів впливу в педагогіці як переконання і навіювання. Довіра викладача всім членам групи виражається в схваленні відповідей своїх учасників, покладання посильних і разом 3 тим складних обов'язків на кожного члена групи, визнання думки, діяльності кожного учасника і т.д. Тільки в атмосфері довіри можливо справжнє співробітництво. Постійність можна уявити як системність діяльності викладача, а звідси і студентів. 
Трудове навчання (технологія), як навчальний предмет, вибивається 3 ряду шкільних дисциплін, які містять основи базових наук. Такої науки як праця немає. Не можна навчити людину працювати «взагалі». Кожен вид праці конкретний і унікальний [1, c.219].

Завдання майбутнього вчителя технологій полягає в тому, щоб показати, яке місце в нашому житті займає праця, переконати дітей, що тільки в праці, розумовій, фізичній, творчий, реалізується особистість, дати теоретичні знання і практичні навички, які потім стануть в нагоді в житті.

Причому вирішувати ці завдання слід працею конкретною і реальною, а не абстрактною і незрозумілою, робити речі і предмети, необхідні в побуті.

Майбутній вчитель технологій повинен володіти так званим інноваційним компонентом: педагогічною діагностикою, рефлексією навчання, проектуванням освітніх систем, конструюванням навчального процесу, що веде до формування у нього нового педагогічного і технологічного мислення.

Сократ порівнював вчителя 3 дощової краплею. Дійсно, як дощ відкриває потенціал кожного зерна, так і мета вчителя - виявити обдарованість кожного учня. Немає на світі нездатних дітей, є глухі і сліпі дорослі, які не вірять або бояться вірити, що їхня дитина - особистість.

Завдання майбутнього вчителя технології - допомогти учневі знайти себе, зробити перше і найважливіше відкриття - відкрити свій творчий хист, а може бути, i талант.

В сучасних умовах змінюється роль викладача і учня в звичному розумінні. Викладач є: джерелом інформації, організатором психологічного клімату, керівником міжособистісних відносин, виступаючи в ролі «фасилітатора» (від англ. facilitate полегшувати) природного його розвитку, який надає необхідні матеріали, ставить проблеми і забезпечує загальне педагогічне керівництво, адекватне функціональному рівню, досягнутому студентом. При цьому роль викладача як керівника повинна бути непомітна для студентів, він виступає скоріше як координатор, провідник, соратник.

Висновок. Таким чином, створення емоційно-позитивного настрою виступає в якості одного $з$ стимулюючих факторів формування комунікативної компетентності майбутнього фахівця.

Все це вимагає знань, навичок, педагогічної майстерності. $Є$ безліч способів зробити уроки цікавими і красивими, але найголовнішим на цьому шляху, на мій 
погляд, є віра в себе, віра в свої можливості, віра в своє велике призначення, а позитивний емоційний стан допомагає в цьому.

\section{Литература:}

1. Андреева И. Н. Эмоциональная компетентность в работе учителя [Текст]// Народное образование. - 2006. -№2. - с. 216-223.

2. Анохин П. К. Эмоции [Текст] // П. К. Анохин, В. Вилюнас Психология эмоций. - СПб: Питер, 2006. - с. 268-275.

3. Вергасов В. М. Активизация познавательной деятельности студентов в высшей школе [Текст] / В. М. Вергасов. - Киев: Выща школа, 1988. - с. 47.

4. Изард К. Психология эмоций [Текст] / К. Изард; пер. с англ. - СПб. : Питер, 2008. $-464 \mathrm{c}$.

5. Тихомиров О. К. Психология мышления [Текст] / О. К. Тихомиров. - М., 1984. -c. 9,88 .

6. Leeper, R. V. A motivational theory of emotion to replace «emotion as disorganised responce» [Text] / R. V. Leeper //Psychol. Rev. - 1948. - V.55. №5.

7. Почепцов Г. Г. Коммуникативные технологии двадцатого века [Текст] / Г. Г. Почепцов. - М.: Рефл-бук, К.: Ваклер, 2000. - 352 с.

8. Сластенин В. А., Педагогика [Текст]: учеб./В. А.Сластенин и др. - М.: ШколаПресc, 1997. - 512 c.

\section{References:}

1. Andreeva I. N. Emocionalnaya kompetentnost' v rabote uchitelya [Emotional competence in the teacher's work]// Narodnoe obrazovanie. - 2006. -№2. - S. 216-223. (in Russian)

2. Anohin P. K., Vilyunas V. Emocii [Emotions] // Psihologiya emociy. - SPb: Piter, 2006. - S. 268-275. (in Russian)

3. Vergasov V. M. Aktivizaciya poznavatelnoy deyatelnosti studentov $\mathrm{v}$ visshey shkole [Activation of cognitive activity of students in higher education] - Kiev: Vischa shkola, 1988. - S. 47. (in Russian)

4. Izard K. Psihologiya emociy [Psychology of emotions] / per. s angl. - SPb. : Piter, 2008. -464 s. (in Russian)

5. Tihomirov O. K. Psihologiya mishleniya [Psychology of Thinking] - M., 1984. - S. 9, 88. (in Russian) 
6. Leeper, R. V. A motivational theory of emotion to replace «emotion as disorganised responce» [Text] / R. V. Leeper //Psychol. Rev. - 1948. - V.55. №5.

7.. Pochepcov G. G. Kommunikativnie tehnologii dvadcatogo veka [Communicative technologies of the twentieth century] - M.: Refl-buk, K.: Vakler, 2000. - 352 s. (in Russian)

8. Slastenin V. A. I dr. Pedagogika [Pedagogy]: ucheb. - M.: Shkola-Press, 1997. 512 s. (in Russian) 